scholars in the USSR as part of the U.S.-Soviet scholarly exchange program created later by the Eisenhower administration.

Born in 24 April 1922, Thaden graduated from the University of Washington in 1943 and served in the United States Navy during World War II. With demobilization after the war, he undertook graduate study at the University of Zurich, Switzerland, in 1947-1948 and then completed his PhD at the University of Paris (Pantheon-Sorbonne) with Pierre Renouvin in 1948-1950. Under Renouvin's direction, Thaden wrote Russia and the Balkan Alliance of 1912, which he reworked into a monograph and published with Pennsylvania State University Press in 1965. After completing his PhD, Thaden returned to the University of Washington, where he taught until 1952 when he joined the faculty at Pennsylvania State University. Over the next sixteen years he established his position as a leader in graduate education at Penn State and, through a series of articles and chapters, confirmed the broad range of his interests-Russian diplomatic history of the early twentieth century, Russian intellectual history, and Russian historiography. In 1964, he published Conservative Nationalism in Nineteenth-Century Russia (University of Washington Press). During his final years at Penn State, Thaden conducted his first seminars on the Russification of the Baltic guberniias and Finland in the late nineteenth century and began work on his textbook of modern Russian history, Russia since 1801: The Making of a New Society (John Wiley, 1971).

In 1968, Thaden accepted a position in the history department of the University of Illinois, Chicago, where he would teach until his retirement in 1992. During those two decades he completed his work on the Baltic guberniias and Finland and, as coeditor with Michael Haltzel, published the collection, Russification in the Baltic Provinces and Finland, 1855-1914 (Princeton University Press, 1981). He followed this with his study of the incorporation of the Polish, Lithuanian, and Ukrainian lands into the Russian empire, which he wrote together with his wife, Marianna Forster Thaden: Russia's Western Borderlands, 1710-1870 (Princeton University Press, 1984). That same year he and Toivo Raun coedited Finland and the Baltic Provinces in the Russian Empire as a special issue of the Journal of Baltic Studies. Interpreting History: Collective Essays on Russia's Relations with Europe (Social Science Monographs, 1990) is a collection of some of Thaden's previously published articles on the theme of Russia and the west grouped around four large themes: historiography, foreign policy, nationalism and nationality policy, and the Baltic provinces. In 1992 Thaden retired from the University of Illinois, Chicago, but he remained actively engaged in research and publishing. His primary area of interest became the shift in Russian historiography in the nineteenth century from an Enlightenment paradigm to one based on historicism and philosophical idealism, and he explored this topic in The Rise of Historicism in Russia (Peter Lang, 1999). In 1995 Leo Schelbert and Nick Ceh coedited Essays in Russian and East European History: Festschrift in Honor of Edward C. Thaden, which includes articles on imperial Russia, eastern Europe, and historiography by his colleagues and former students. This work also contains a bibliography of his publications to that date. Thaden remained actively involved in research and professional activities associated with Slavic and Baltic studies until his death. An ardent supporter of the study and teaching of history, he was a founding member of the National History Center in Washington, D.C.

An inspiration to his students and colleagues alike, Thaden will be deeply missed by two generations of scholars who benefited from his intellect, professionalism, and personal charm.

JaCOB W. KIPP

School of Advanced Military Studies July 2008

\title{
Charles E. Timberlake, 1935-2008
}

When Charles Timberlake learned in March 2007 that he had a rare form of melanoma, he was determined to deal with it in the same tenacious and focused fashion that he had dealt with the many professional challenges and responsibilities he had faced during his 
long and productive academic career. His year-long struggle with the disease ended on 21 March 2008.

Charles was born on 9 September 1935, in Greenup County, Kentucky, and spent his early years in the hills of Appalachia. A series of fortuitous encounters with caring teachers enabled him to leave Appalachia and begin his higher education, first at Berea College in Kentucky (which granted him its Distinguished Alumnus Award in 2002), then at Claremont Graduate School, and, ultimately, at the University of Washington, where he earned the PhD in Russian history in 1968. In the fall of 1967, he began his lengthy and productive academic career at the University of Missouri, where he would remain until his retirement in 2004.

Those of us who interacted with him as friends and colleagues will remember Charles as a person of boundless energy and enthusiasm. For almost four decades, we watched him dashing off to class, often at the last minute, with bundles of bulging folders and books under his arm. His enthusiasm for all things Russian was infectious. An exemplary teacher and mentor to hundreds of undergraduates and scores of graduate students, he was also a great believer in good writing, which prompted him to designate many of his courses "writing intensive," with the unenviable corollary of providing him with scores of essays to grade during the course of a semester.

His broad and varied research interests included: the zemstvos (particularly Tver province and I. I. Petrunkevich, on whom he was working at the time of his death), Russian liberalism, education policy, religious (particularly monastic) institutions, U.S.-Soviet relations, and post-Soviet rural sociology. Even before he had completed the $\mathrm{PhD}$ and begun his academic career, the name of Charles Timberlake was well known to Slavists, especially younger scholars planning to do research at the splendid University of Helsinki library. In September 1966, Slavic Review published his widely read and frequently consulted essay, "The Slavic Department of the Helsinki University Library" (vol. 25, no. 3). In addition to a number of edited volumes of essays and documents, Charles published a variety of articles and more than a dozen book chapters. He was a frequent contributor to The Modern Encyclopedia of Russian and Soviet History, with some eighteen entries in all. In 1992, he was selected by a group of former PhD students at the University of Washington to serve as editor of a Festschrift honoring his former mentor (and longtime editor of Slavic Review), Donald W. Treadgold. His more recent publications include: The Fate of Russian Orthodox Monasteries and Convents since 1917 (University of Washington Press, 1995) and the jointly authored (with David O'Brien and others), Services and Quality of Life in Rural Villages of the Former Soviet Union: Data from 1991 and 1993 (University Press of America, 1998).

Charles was a tireless advocate and promoter of Russian and Soviet studies on many levels: international, national, regional, and local. He taught and lectured abroad at universities and academies of science in England, Russia, Georgia, China, and Finland (where he taught a special short course on Russian history at Joensuu University on a regular basis from 2003 to 2006). In 2002, the University of Missouri recognized his contribution to the international academic community by bestowing upon him the Provost's Award for Leadership in International Education. At the national level, he served on the Board of Directors of the American Association for the Advancement of Slavic Studies from 1980 to 1982 and again from 1984 to 1986 . Regionally, he was president of the Central Slavic Conference five times and a member of its Executive Board from 1972 until his death. Closer to home, he served as department chair in the Department of History from 1996 to 2000. Many of his faculty colleagues at Missouri, both in history and outside the department, especially in German and Russian studies, will remember Charles as an indefatigable supporter of and advocate for the university library. His determined effort to preserve and build upon its uncommonly excellent Slavic collection ranks among his major contributions to the university.

Charles earned the respect and admiration of those who knew him for his devotion to his family. Early in his career, he moved out of the city of Columbia to Clearview Farms so that his young sons, Mark, Dan, and Eric (and eventually his nine grandchildren) would have more space and freedom to roam. His wife, Patricia, was a frequent companion on his numerous research trips and teaching engagements abroad. Together with family and 
friends, they had planned to celebrate their fiftieth wedding anniversary in December 2008.

\author{
Russ ZGuTA \\ University of Missouri \\ April 2008
}

\title{
Josephine Woll, 1950-2008
}

Josephine Woll, Josie to her many friends, died on 12 March 2008 just a few days before her fifty-eighth birthday. In the course of her long illness she had endured numerous bouts of chemotherapy with exceptional fortitude.

Josie grew up in the Bronx, the youngest of three sisters, and a member of a closeknit Jewish family. In public school, Josie skipped two years, so she entered William Smith College in Geneva, New York, at age 16 and graduated in 1970 with a major in comparative literature. She attended graduate school at the University of North Carolina, Chapel Hill, and received her $\mathrm{PhD}$ in Russian language and literature, writing her dissertation on Aleksandr Pushkin. After teaching briefly at Duke University, she moved to Washington, D.C., in 1977 and began working at Howard University, where she spent the remainder of her academic career.

In 1977, Josie married Abraham Brumberg, a scholar, journalist, and former editor of Problems of Communism. They lived together happily for thirty-one years until Abe's recent death. Both of them were sociable people, and they had a large circle of friends. In Chevy Chase they maintained what can best be described as an intellectual salon. With their wit and broad interests, they had a remarkable talent for bringing people together, and evenings at their home were always pleasant and stimulating. (In addition to her other talents Josie was an excellent cook.)

Josie's exceptionally wide interests were well reflected in her scholarship. Her first published work was an annotated bibliography of Soviet samizdat literature that she and Vladimir G. Treml brought out in 1978 (and republished in an expanded form in 1983): Soviet Dissident Literature: A Critical Guide. In 1991 she published Invented Truth, a study of the writings of Iurii Trifonov, arguably the best writer of the late Soviet period. A sophisticated critic with an excellent knowledge of Soviet reality, Josie demonstrated Trifonov's adroit strategy for expressing heterodox thoughts at a time of strict censorship. From reading her book, one learns that Trifonov was not only a critic of the Soviet world in which he lived and of his nation's bitter and bloody past but also a skilled writer whose work has remained interesting even decades after the passing of the Soviet state.

Josie later became interested in Soviet film and, in 2000, published Real Images; Soviet Cinema and the Thaw. Just like her work on Trifonov, this book reflects the duality of her interests. On the one hand the book is a contribution to our knowledge of this remarkable period of Soviet history, but on the other it is a work from which the reader can gain an understanding of the artistic quality of the films that she discussed. Josie continued to publish widely on Soviet cinema, writing reviews and articles. She also wrote two volumes in the Tauris "film companion series," one on the Cranes Are Flying (2003) and the other on Repentance (2001, written together with her friend, Denise Youngblood).

Josie also had an abiding interest in the history of Russian and Soviet Jewry, and she published reviews and articles on this topic. The knowledge of Yiddish that she had acquired as a girl was put to good use.

Those of us who had the good fortune to know Josie well remember her as a woman of great warmth and strength, someone with a talent for friendship, and altogether the best human being among our friends. We miss her terribly.

Peter Kenez

University of California, Santa Cruz April 2008 